\title{
Milk fatty acid profile related to energy balance in dairy cows
}

\author{
Josef Gross ${ }^{1}$, Hendrika A van Dorland ${ }^{2}$, Rupert M Bruckmaier ${ }^{2}$ and Frieder J Schwarz ${ }^{1}$ * \\ ${ }^{1}$ Department of Animal Sciences, Chair of Animal Nutrition, Technical University of Munich, Liesel-Beckmann-Str. 6, D-85350 \\ Freising-Weihenstephan, Germany \\ ${ }^{2}$ Veterinary Physiology, Vetsuisse Faculty, University of Bern, Bremgartenstr. 109a, CH-3001 Bern, Switzerland
}

Received 2 May 2011; accepted for publication 14 July 2011; first published online 16 August 2011

\begin{abstract}
Milk fatty acid (FA) profile is a dynamic pattern influenced by lactational stage, energy balance and dietary composition. In the first part of this study, effects of the energy balance during the proceeding lactation [weeks 1-21 post partum (pp)] on milk FA profile of 30 dairy cows were evaluated under a constant feeding regimen. In the second part, effects of a negative energy balance (NEB) induced by feed restriction on milk FA profile were studied in 40 multiparous dairy cows (20 feed-restricted and 20 control). Feed restriction (energy balance of $-63 \mathrm{MJ} \mathrm{NEL/d}$, restriction of $49 \%$ of energy requirements) lasted 3 weeks starting at around 100 days in milk. Milk FA profile changed markedly from week $1 \mathrm{pp}$ up to week $12 \mathrm{pp}$ and remained unchanged thereafter. The proportion of saturated FA (predominantly 10:0, 12:0, 14:0 and 16:0) increased from week $1 \mathrm{pp}$ up to week $12 \mathrm{pp}$, whereas monounsaturated FA, predominantly the proportion of $18: 1,9 \mathrm{C}$ decreased as NEB in early lactation became less severe. During the induced NEB, milk FA profile showed a similarly directed pattern as during the NEB in early lactation, although changes were less marked for most FA. Milk FA composition changed rapidly within one week after initiation of feed restriction and tended to adjust to the initial composition despite maintenance of a high NEB. C18:1,9c was increased significantly during the induced NEB indicating mobilization of a considerable amount of adipose tissue. Besides $18: 1,9 \mathrm{C}$, changes in saturated FA, monounsaturated FA, de-novo synthesized and preformed FA (sum of FA $>$ C16) reflected energy status in dairy cows and indicated the NEB in early lactation as well as the induced NEB by feed restriction.
\end{abstract}

Keywords: Milk fat, fatty acids, energy balance, dairy cow.

Milk fat is the main component determining energy expenditure for milk production in dairy cows. It consists almost completely of triglycerides (Moate et al. 2007). Due to proceeding analytical improvements, up to now more than 400 individual fatty acids (FA) in milk fat are documented (Jensen et al. 1991; Moate et al. 2007). During the last decades, milk FA composition has gained the interest of manufacturers and consumers as it influences nutritional, physical and flavour properties of dairy products (Bobe et al. 2007). Changes in the degree of FA unsaturation have an impact on oxidative stability during milk processing (Kay et al. 2005; Glantz et al. 2009). The focus of research regarding the impact of milk FA on human health was especially set on conjugated linoleic acids (CLA) and other polyunsaturated FA (18:2, 18:3) (e.g. Kelsey et al. 2003; Palladino et al. 2009). Dietary manipulation to directly

*For correspondence; e-mail: schwarzf@wzw.tum.de influence the content of these FA is documented in over 100 publications during the last decade (Moate et al. 2007). Thus nutrition is one of the main factors influencing milk FA composition.

Besides diet, lactational stage along with energy balance of dairy cows have an impact on FA profile in cows' milk (Kay et al. 2005; Stoop et al. 2009). During the first couple of weeks after parturition, the occurrence of a negative energy balance (NEB) is common in dairy cows. The deficiency of nutrients and energy is compensated by mobilization of body reserves, predominantly adipose tissue associated with the release of FA. During insufficient supply and quality of feed, a NEB may also occur later in lactation as reported for pastured dairy cows averaging 94 days in milk (DIM) (Leiber et al. 2005). The specific effect of a NEB on milk FA composition was shown in a few earlier studies such as Luick \& Smith (1963), who fasted high-yielding dairy cows for $5 \mathrm{~d}$ to induce a clinical ketosis or Dann et al. (2005), who enhanced the post partum (pp) NEB by feed restriction. 


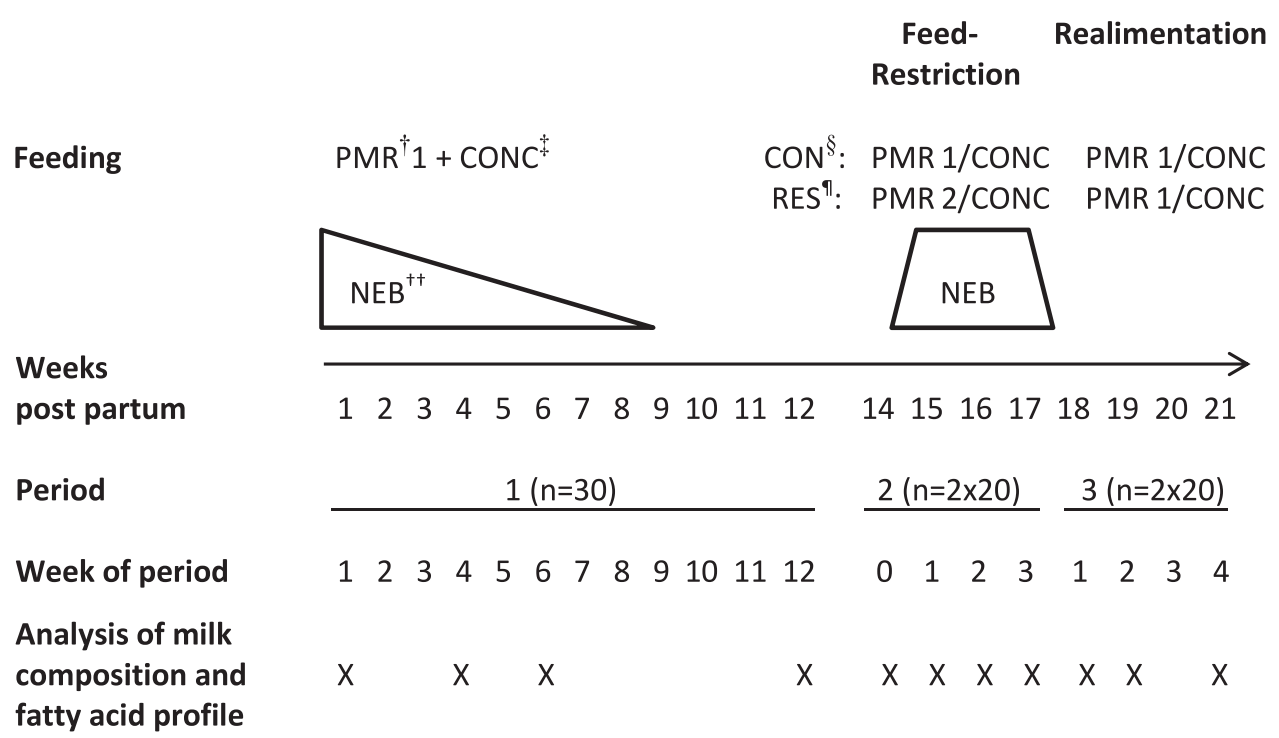

Fig. 1. Experimental design.

+ Partial mixed ration

₹ Concentrate

$\S$ Control group

I Feed-restricted group

t+ Negative energy balance

The focus of the present study is set on the interactions between energy balance and milk FA profile in dairy cows. Contrary to earlier studies, the present study investigated effects of both the NEB in early lactation and a deliberately induced NEB by feed restriction at around 100 DIM.

\section{Materials and Methods}

\section{Animal trial}

Fig. 1 shows the experimental schedule of the present study. Detailed information on the animal trial and feeding regimen is given in Gross et al. (2011). In brief, the study was conducted with multiparous Holstein dairy cows $(3 \cdot 1 \pm 0 \cdot 2$ parities, mean \pm SEM) kept in a free stall barn and covered three experimental periods beginning with parturition. Experimental period 1 (from parturition up to week 12 pp) included 40 cows that were treated similarly. However, only milk samples from 30 out of the 40 cows were obtained for FA analysis at all time points in period 1. In period 2 at around 100 DIM (week 14 pp), cows were divided equally into either a control (CON; $n=20)$ or a restriction group (RES; $n=20$ ) with feed restriction for 3 weeks (weeks 15 to $17 \mathrm{pp}$, Fig. 1). After 3 weeks of the deliberately induced NEB, period 3 (weeks 18 to 21 pp, Fig. 1) started, where RES cows were (re)fed similarly to CON cows. Throughout the study, all animals, except RES cows in feed restriction, had free access to a partial mixed ration 1 (PMR 1; 33.7\% grass silage, $44.9 \%$ corn silage, $6.5 \%$ hay and $14.9 \%$ concentrate on a DM basis). Intake of PMR was recorded individually by troughs connected to electronic balances. When milk yield was above $21 \mathrm{~kg} / \mathrm{d}$, additional concentrate (CONC, based on barley, wheat, corn kernels, soybean meal, dried sugar beet pulp with molasses) including a vitamin-mineral premix was fed individually according to milk yield in transponder feeding stations $(0.4 \mathrm{~kg} \mathrm{CONC} / \mathrm{kg}$ milk; maximum of $8.9 \mathrm{~kg}$ $\mathrm{CONC} / \mathrm{d}$ ). In order to induce an energy deficiency of at least $30 \%$ of cows' requirements at the start of period 2, RES cows received a limited amount of a similar diet as the CON cows, but mixed with an additional $25 \%$ of hay (PMR 2) and a limited amount of $\operatorname{CONC}(0.4 \mathrm{~kg} / \mathrm{d})$. Nutrient values of PMR 1, PMR 2 and CONC are described in Gross et al. (2011).

\section{Determination of energy balance}

Individual feed intake (PMR and CONC) and milk yield were recorded daily, body weight weekly. Components of the diets were analysed for crude ash, crude fibre, crude protein and crude fat according to the Weende analysis (Naumann et al. 2000) and from that their energy content was calculated according to the German Society of Nutrition Physiology (GfE, 2001). The energy content of PMR 1, PMR 2 and CONC was calculated by multiplying the energy density of the single components with their relative proportion in the diets. Energy content of milk as well as the energetic requirement for maintenance were determined according to GfE (2001). The difference between energy 
intake by feed and energy expenditure for maintenance and milk production (net energy lactation) results in the energy balance of the individual cow.

\section{Analysis of milk composition, and FA composition of milk and diets}

After parturition, cows were milked twice daily (5.00 and 15.00) and milk yield was recorded. Milk samples were pooled once per week from two consecutive milkings, Monday evening and Tuesday morning. Obtained milk aliquots were analysed for milk fat, protein and lactose by an infrared-spectrophotometer (MilkoScan-FT-6000, Foss Analytical A/S, Hillerød, Denmark) in the laboratory of the Milchprüfring Bayern e. V., Wolnzach, Germany. A second aliquot was stored at $-20^{\circ} \mathrm{C}$ until analysis for FA composition. Milk FA composition was determined in weeks 1 , 4,6 and 12 pp of period 1, weekly during period 2 and in weeks 1, 2 and 4 of period 3.

Milk fat was extracted according to Bligh \& Dyer (1959), modified by Hallermayer (1976). Total fat from feed samples was extracted according to Naumann et al. (2000). FA composition of milk and feed samples was determined using FA methyl esters (FAME) prepared by transesterification with trimethylsulphonium hydroxide (TMSH). FAME were injected into a gas chromatograph (GC 6890, Agilent Technologies, Waldbronn, Germany) with a flameionization detector and a DB23 column (Agilent Technologies, Waldbronn, Germany; $60 \mathrm{~m} \times 0.25 \mathrm{~mm}$ inner diameter, $0.25 \mu \mathrm{m}$ film). The carrier gas was hydrogen (constant flow at $1.0 \mathrm{ml} / \mathrm{min}$ ). Samples were injected by split injection (split ratio $1: 100$ ). The oven temperature was increased from $50{ }^{\circ} \mathrm{C}$ to $175^{\circ} \mathrm{C}$ at $5 \mathrm{deg} \mathrm{C}$ per min, from $175^{\circ} \mathrm{C}$ to $220^{\circ} \mathrm{C}$ at $3.3 \mathrm{deg} \mathrm{C}$ per min, held for $7.25 \mathrm{~min}$, increased from $220^{\circ} \mathrm{C}$ to $250{ }^{\circ} \mathrm{C}$ at $10 \mathrm{deg} \mathrm{C}$ per min and held for $5 \mathrm{~min}$. The detector temperature was $260^{\circ} \mathrm{C}$. FA were quantified with Chromeleon 6.8 Chromatography Software (Dionex, Sunnyvale CA, USA) using a FAME mix (Sigma Aldrich, St. Louis MO, USA) as standard. FA composition of PMR 1, PMR 2 and CONC is shown in Table 1.

\section{Statistical analysis}

Data presented in text and tables are means \pm SEM of individual measurements in each cow. Relations between energy balance and FA were expressed by the Pearson correlation coefficient. Changes in energy balance, feed intake, milk yield, milk composition and milk FA profile over time during lactation and feed restriction with subsequent realimentation were evaluated by a mixed model in SAS, version 9.2 (SAS Institute, Cary NC, USA) with group, week and the group $\times$ week interaction as fixed effect. Differences over time and within groups during feed restriction (period 2) and realimentation (period 3) were detected by Bonferroni's $t$ test. $P$ values $<0.05$ were considered to be significant.
Table 1. Fatty acid (FA) composition (g/100 g of fatty acid methyl esters, FAME) of experimental diets and concentrate (CONC)

\begin{tabular}{|c|c|c|c|}
\hline & PMRt 1 & PMR 2 & CONC \\
\hline Crude fat (g/kg DM) & 30 & 23 & 21 \\
\hline \multicolumn{4}{|l|}{ FA (g/100 g FAME) } \\
\hline 14:0 & $0 \cdot 50$ & $0 \cdot 65$ & $0 \cdot 19$ \\
\hline 16:0 & $16 \cdot 93$ & $19 \cdot 97$ & $27 \cdot 80$ \\
\hline $16: 1,9 c$ & $0 \cdot 28$ & $0 \cdot 39$ & $0 \cdot 16$ \\
\hline 18:0 & $2 \cdot 72$ & $2 \cdot 57$ & $4 \cdot 18$ \\
\hline $18: 1,9 t$ & $0 \cdot 10$ & $0 \cdot 12$ & $0 \cdot 08$ \\
\hline $18: 1,9 c$ & $15 \cdot 90$ & $13 \cdot 32$ & $20 \cdot 49$ \\
\hline $18: 1,11 \mathrm{C}$ & $1 \cdot 02$ & 0.92 & $1 \cdot 47$ \\
\hline $18: 2,9 c, 12 C$ & $37 \cdot 57$ & $33 \cdot 36$ & $38 \cdot 70$ \\
\hline $18: 3,9 c, 12 c, 15 c$ & $18 \cdot 59$ & $21 \cdot 33$ & $2 \cdot 66$ \\
\hline Others and unidentified peaks & $6 \cdot 39$ & $7 \cdot 38$ & $4 \cdot 26$ \\
\hline
\end{tabular}

\section{Results and Discussion}

Changes in milk composition and milk FA profile with altering energy balance post partum

Data on energy balance, feed intake, milk yield, milk composition and FA profile are shown in Tables 2 and 3. Lactational stage clearly affected daily milk yield and milk composition. Daily milk yield increased up to week 6 pp and declined thereafter (Table 2). Milk fat and protein contents decreased from week $1 \mathrm{pp}$ up to week $6 \mathrm{pp}$ and slightly increased thereafter, whereas lactose content was relatively constant from week 4 pp onwards (Table 2). With progressing lactation and improvement of energy balance through increasing feed intake, especially milk FA profile markedly changed (Table 3). Energy balance in dairy cows was most negative in week $1 \mathrm{pp}$ and improved with increasing feed intake, but was still negative in week 6 pp (Table 2). In order to compensate the insufficient energy intake pp, considerable amounts of body fat are mobilized resulting in elevated plasma concentrations of non-esterified FA (NEFA) and beta-hydroxybutyrate (BHBA). During the $\mathrm{NEB}$ in early lactation, plasma glucose concentration in the present study showed a nadir of $3 \cdot 30 \pm 0 \cdot 04 \mathrm{mmol} / \mathrm{l}$ in week $2 \mathrm{pp}$, whereas plasma concentrations were highest for NEFA in week $2 \mathrm{pp}(0.90 \pm 0.06 \mathrm{mmol} / \mathrm{l})$ and for BHBA in week $3 \mathrm{pp}$ $(0.98 \pm 0 \cdot 14 \mathrm{mmol} / \mathrm{l}$; Gross et al. 2011). After the observed peak of lactation, energy requirements could be met by consumed feed resulting in a positive energy balance.

Basically, milk FA can be derived from four major pathways: the diet, the mammary gland (de-novo synthesis), the rumen (biohydrogenation, bacterial degradation and synthesis), and body fat mobilization (Stoop et al. 2009). Changes in milk FA composition during lactation originate from altered activities in these pathways (Van Knegsel et al. 2005; Stoop et al. 2009).

For the evaluation of changes in milk composition and milk FA profile in the present study with altering energy balance pp depending on the same feeding regimen, data 
Table 2. Daily milk yield and milk composition in weeks 1, 4, 6, 12 (all animals), 17 and 21 (control group) post partum. Values without a common superscript letter are significantly different $(P<0 \cdot 05)$

\begin{tabular}{|c|c|c|c|c|c|}
\hline $\begin{array}{l}\text { Week } 1 \\
(n=30)\end{array}$ & $\begin{array}{l}\text { Week } 4 \\
(n=30)\end{array}$ & $\begin{array}{l}\text { Week } 6 \\
(n=30)\end{array}$ & $\begin{array}{l}\text { Week } 12 \\
(n=30)\end{array}$ & $\begin{array}{l}\text { Week } 17 \\
(n=20)\end{array}$ & $\begin{array}{l}\text { Week } 21 \\
(n=20)\end{array}$ \\
\hline $13 \cdot 7^{\mathrm{b}}$ & $14 \cdot 3^{b}$ & $14 \cdot 3^{b}$ & $17 \cdot 1^{\mathrm{a}}$ & $16 \cdot 9^{\mathrm{a}}$ & $17 \cdot 8^{\mathrm{a}}$ \\
\hline $\pm 0 \cdot 3$ & $\pm 0 \cdot 3$ & $\pm 0 \cdot 3$ & $\pm 0 \cdot 4$ & $\pm 0 \cdot 4$ & $\pm 0 \cdot 5$ \\
\hline $1 \cdot 6^{\mathrm{e}}$ & $5 \cdot 7^{b}$ & $7 \cdot 6^{\mathrm{a}}$ & $5 \cdot 8^{\mathrm{b}}$ & $4 \cdot 7^{\mathrm{C}}$ & $3 \cdot 6^{\mathrm{d}}$ \\
\hline $\pm 0 \cdot 0$ & $\pm 0 \cdot 1$ & $\pm 0 \cdot 2$ & $\pm 0 \cdot 3$ & $\pm 0 \cdot 5$ & $\pm 0 \cdot 5$ \\
\hline$-45 \cdot 0^{d}$ & $-24 \cdot 8^{c}$ & $-9 \cdot 5^{b}$ & $9 \cdot 1^{\mathrm{a}}$ & $8 \cdot 9^{a}$ & $12 \cdot 2^{\mathrm{a}}$ \\
\hline $\pm 3 \cdot 9$ & $\pm 3 \cdot 2$ & $\pm 3 \cdot 1$ & $\pm 2 \cdot 7$ & $\pm 4 \cdot 7$ & $\pm 3 \cdot 1$ \\
\hline $27 \cdot 4^{c}$ & $37 \cdot 5^{a}$ & $39 \cdot 3^{a}$ & $33 \cdot 5^{b}$ & $29 \cdot 7^{\mathrm{C}}$ & $27 \cdot 6^{c}$ \\
\hline $\pm 0 \cdot 8$ & $\pm 0 \cdot 8$ & \pm 0.9 & $\pm 1 \cdot 2$ & $\pm 1 \cdot 3$ & $\pm 1 \cdot 2$ \\
\hline $34 \cdot 1^{b}$ & $40 \cdot 6^{a}$ & $40 \cdot 3^{a}$ & $34 \cdot 9^{\mathrm{b}}$ & $31 \cdot 9^{b c}$ & $29 \cdot 8^{\mathrm{C}}$ \\
\hline $\pm 1 \cdot 2$ & $\pm 1 \cdot 1$ & $\pm 1 \cdot 1$ & $\pm 1 \cdot 2$ & $\pm 1 \cdot 4$ & $\pm 1 \cdot 2$ \\
\hline $5 \cdot 60^{\mathrm{a}}$ & $4 \cdot 56^{\mathrm{b}}$ & $4 \cdot 17^{\mathrm{C}}$ & $4 \cdot 31^{\mathrm{bc}}$ & $4 \cdot 48^{\mathrm{bc}}$ & $4 \cdot 54^{b}$ \\
\hline $\pm 0 \cdot 14$ & $\pm 0 \cdot 10$ & $\pm 0 \cdot 09$ & $\pm 0 \cdot 10$ & \pm 0.08 & \pm 0.09 \\
\hline $4 \cdot 12^{\mathrm{a}}$ & $3 \cdot 05^{d}$ & $3 \cdot 09^{d}$ & $3 \cdot 32^{c}$ & $3 \cdot 43^{\mathrm{bc}}$ & $3 \cdot 50^{b}$ \\
\hline $\pm 0 \cdot 06$ & $\pm 0 \cdot 04$ & $\pm 0 \cdot 04$ & $\pm 0 \cdot 05$ & \pm 0.06 & $\pm 0 \cdot 05$ \\
\hline $4 \cdot 46^{b}$ & $4 \cdot 77^{\mathrm{a}}$ & $4 \cdot 79^{a}$ & $4 \cdot 76^{\mathrm{a}}$ & $4 \cdot 75^{\mathrm{a}}$ & $4 \cdot 72^{\mathrm{a}}$ \\
\hline \pm 0.03 & $\pm 0 \cdot 02$ & $\pm 0 \cdot 02$ & $\pm 0 \cdot 02$ & \pm 0.02 & \pm 0.03 \\
\hline
\end{tabular}

† Partial mixed ration

‡Concentrate

from all animals in period 1 and CON group in periods 2 and 3 were evaluated in order to investigate the effect of continuous lactation. In the present study, most changes in milk FA profile took place during the observed NEB from weeks 1 to $6 \mathrm{pp}$, while FA composition was relatively constant between weeks 12 and 21 pp. FA up to 16:0 showed lowest proportions in week $1 \mathrm{pp}$ that increased to relatively constant proportions from week 12 onwards (Table 3). These findings agree with earlier studies (Stull et al. 1966; Palmquist et al. 1993; Kay et al. 2005; Garnsworthy et al. 2006). Confirming results of Stoop et al. (2009), saturated FA (SFA), especially 16:0 increased from weeks 1 to $12 \mathrm{pp}$ in the present study (Fig. 2), while monounsaturated FA (MUFA), mainly represented by 18:1,9c decreased until week 12 pp with improving energy balance (Table 2). The proportion of polyunsaturated FA (PUFA) was relatively constant from week 1 up to week 21 pp (Table 3). Due to the increased adipose tissue mobilization during the NEB in early lactation, preformed FA concentrations (sum of FA $>$ C16) were greatest in week $1 \mathrm{pp}$ and decreased in a similar pattern to that reported by Kay et al. (2005). Oleic acid $(18: 1,9 c)$ is the predominant FA in adipocytes and primarily released through lipolysis during NEB (Rukkwamsuk et al. 2000). Plasma NEFA and triglycerides are utilized by the mammary gland for milk FA synthesis (Moore \& Christie, 1979). The high transfer rate of $18: 1,9 \mathrm{c}$ from plasma into milk fat (Tyburczy et al. 2008) confirms the elevated proportion of $18: 1,9 \mathrm{C}$ in milk fat during the NEB pp in the present study. Especially long-chain FA are derived from plasma and incorporated into milk fat (Palmquist et al. 1993) and inhibit the de-novo synthesis of short-chain FA by the mammary gland (Bauman \& Davis, 1974). The observed increase in short-chain FA with progressing lactation in the present study is consistent with the decreasing adipose tissue mobilization at around weeks 4-6 pp (Garnsworthy \& Huggett, 1992; Palmquist et al. 1993).

Contrary to the findings of Stoop et al. (2009), trans FA slightly increased with improved energy balance of dairy cows in the present study (Table 3). The proportion of CLA in milk fat remained constant from week 1 to week 12 pp and increased slightly thereafter up to week $21 \mathrm{pp}$. Milk FA from de-novo synthesis ( $\leqslant \mathrm{C} 14$ and part of $\mathrm{C} 16)$ in the present study increased from week 1 pp up to week 12 pp (Fig. 2) in agreement with Palmquist et al. (1993) and Kay et al. (2005). Although the FA synthesized de novo comprise approximately $40 \%$ by weight over the entire lactation, preformed FA contribute a larger portion of the total FA in early lactation (Kay et al. 2005). Percentage of preformed FA decreased up to week $12 \mathrm{pp}$ in the present study. Thereafter milk composition and milk FA profile were stable until the end of the study. Garnsworthy et al. (2006) concluded that stage of lactation does not affect the relative incorporation of denovo synthesized and preformed FA when the composition of diets remains constant. Because of the same feeding regimen in the present study, changes in milk FA profile regarding de-novo synthesized and preformed FA therefore reflect changes in energy balance of dairy cows.

\section{Changes in milk and milk FA composition during feed restriction and subsequent realimentation}

Due to feed restriction in period 2, RES cows experienced a significant NEB in weeks 15 to 17 pp being even more intense compared with the NEB occurring in the first 6 weeks 
Table 3. Milk fatty acid (FA) composition (g/100 g of fatty acid methyl esters, FAME) in weeks 1, 4, 6, 12 (all animals), 17 and 21 (control group) post partum. Values without a common superscript letter are significantly different $(P<0 \cdot 05)$

\begin{tabular}{|c|c|c|c|c|c|}
\hline $\begin{array}{l}\text { Week } 1 \\
(n=30)\end{array}$ & $\begin{array}{l}\text { Week } 4 \\
(n=30)\end{array}$ & $\begin{array}{l}\text { Week } 6 \\
(\mathrm{n}=30)\end{array}$ & $\begin{array}{l}\text { Week } 12 \\
(\mathrm{n}=30)\end{array}$ & $\begin{array}{l}\text { Week } 17 \\
(\mathrm{n}=20)\end{array}$ & $\begin{array}{l}\text { Week } 21 \\
(\mathrm{n}=20)\end{array}$ \\
\hline $3 \cdot 85^{\mathrm{a}}$ & $3 \cdot 54^{\mathrm{b}}$ & $3 \cdot 38^{\mathrm{b}}$ & $3 \cdot 14^{\mathrm{c}}$ & $3 \cdot 10^{\mathrm{C}}$ & $3 \cdot 15^{\mathrm{c}}$ \\
\hline $\pm 0 \cdot 12$ & $\pm 0 \cdot 11$ & $\pm 0 \cdot 08$ & $\pm 0 \cdot 07$ & $\pm 0 \cdot 07$ & $\pm 0 \cdot 07$ \\
\hline $2 \cdot 21^{\mathrm{c}}$ & $2 \cdot 41^{\mathrm{ab}}$ & $2.55^{\mathrm{a}}$ & $2 \cdot 40^{\mathrm{abc}}$ & $2 \cdot 39^{\mathrm{abc}}$ & $2 \cdot 34^{\mathrm{bc}}$ \\
\hline $\pm 0 \cdot 11$ & \pm 0.08 & \pm 0.05 & \pm 0.06 & $\pm 0 \cdot 04$ & $\pm 0 \cdot 04$ \\
\hline $1 \cdot 16^{\mathrm{C}}$ & $1 \cdot 39^{b}$ & $1 \cdot 58^{\mathrm{a}}$ & $1 \cdot 50^{\mathrm{ab}}$ & $1 \cdot 51^{\mathrm{ab}}$ & $1 \cdot 49^{\mathrm{ab}}$ \\
\hline $\pm 0 \cdot 08$ & \pm 0.06 & \pm 0.04 & $\pm 0 \cdot 04$ & $\pm 0 \cdot 03$ & $\pm 0 \cdot 02$ \\
\hline $2 \cdot 24^{\mathrm{C}}$ & $2 \cdot 82^{b}$ & $3 \cdot 52^{\mathrm{a}}$ & $3 \cdot 52^{\mathrm{a}}$ & $3 \cdot 61^{\mathrm{a}}$ & $3 \cdot 56^{\mathrm{a}}$ \\
\hline $\pm 0 \cdot 18$ & $\pm 0 \cdot 16$ & $\pm 0 \cdot 13$ & $\pm 0 \cdot 10$ & \pm 0.08 & \pm 0.06 \\
\hline $0 \cdot 12^{\mathrm{d}}$ & $0 \cdot 21^{\mathrm{c}}$ & $0 \cdot 27^{b}$ & $0 \cdot 31^{\mathrm{ab}}$ & $0 \cdot 32^{\mathrm{a}}$ & $0 \cdot 34^{\mathrm{a}}$ \\
\hline $\pm 0 \cdot 01$ & $\pm 0 \cdot 01$ & $\pm 0 \cdot 01$ & $\pm 0 \cdot 01$ & $\pm 0 \cdot 01$ & $\pm 0 \cdot 01$ \\
\hline $2 \cdot 37^{\mathrm{C}}$ & $2 \cdot 96^{b}$ & $3 \cdot 83^{\mathrm{a}}$ & $4 \cdot 07^{a}$ & $4 \cdot 27^{\mathrm{a}}$ & $4 \cdot 26^{\mathrm{a}}$ \\
\hline $\pm 0 \cdot 20$ & $\pm 0 \cdot 18$ & $\pm 0 \cdot 18$ & $\pm 0 \cdot 13$ & $\pm 0 \cdot 11$ & $\pm 0 \cdot 08$ \\
\hline $0.03^{\mathrm{e}}$ & $0.05^{d}$ & $0.07^{\mathrm{C}}$ & $0.09^{b}$ & $0 \cdot 10^{\mathrm{ab}}$ & $0 \cdot 10^{\mathrm{a}}$ \\
\hline $\pm 0 \cdot 00$ & $\pm 0 \cdot 00$ & $\pm 0 \cdot 01$ & $\pm 0 \cdot 00$ & $\pm 0 \cdot 00$ & $\pm 0 \cdot 00$ \\
\hline $0.07^{\mathrm{b}}$ & $0 \cdot 06^{b}$ & $0 \cdot 07^{b}$ & $0 \cdot 08^{b}$ & $0 \cdot 10^{\mathrm{a}}$ & $0 \cdot 11^{\mathrm{a}}$ \\
\hline $\pm 0 \cdot 00$ & $\pm 0 \cdot 01$ & $\pm 0 \cdot 01$ & $\pm 0 \cdot 01$ & \pm 0.00 & $\pm 0 \cdot 01$ \\
\hline $8 \cdot 82^{\mathrm{C}}$ & $9 \cdot 75^{b}$ & $11 \cdot 36^{\mathrm{a}}$ & $12 \cdot 06^{\mathrm{a}}$ & $12 \cdot 18^{\mathrm{a}}$ & $12 \cdot 22^{\mathrm{a}}$ \\
\hline $\pm 0 \cdot 48$ & $\pm 0 \cdot 32$ & $\pm 0 \cdot 28$ & $\pm 0 \cdot 23$ & \pm 0.17 & $\pm 0 \cdot 14$ \\
\hline $0 \cdot 62^{b}$ & $1 \cdot 58^{\mathrm{a}}$ & $1 \cdot 00^{\mathrm{a}}$ & $1 \cdot 17^{\mathrm{a}}$ & $1 \cdot 07^{\mathrm{a}}$ & $1 \cdot 36^{\mathrm{a}}$ \\
\hline $\pm 0 \cdot 04$ & $\pm 0 \cdot 04$ & $\pm 0 \cdot 08$ & $\pm 0 \cdot 12$ & $\pm 0 \cdot 05$ & $\pm 0 \cdot 13$ \\
\hline $0 \cdot 64^{\mathrm{c}}$ & $0.74^{\mathrm{c}}$ & $0.98^{b}$ & $1 \cdot 15^{\mathrm{ab}}$ & $1 \cdot 22^{\mathrm{a}}$ & $1 \cdot 17^{\mathrm{a}}$ \\
\hline \pm 0.03 & \pm 0.05 & $\pm 0 \cdot 09$ & \pm 0.07 & $\pm 0 \cdot 04$ & $\pm 0 \cdot 04$ \\
\hline $0 \cdot 18^{\mathrm{c}}$ & $0 \cdot 17^{\mathrm{C}}$ & $0 \cdot 17^{\mathrm{C}}$ & $0 \cdot 20^{b c}$ & $0 \cdot 22^{\mathrm{ab}}$ & $0 \cdot 24^{\mathrm{a}}$ \\
\hline $\pm 0 \cdot 01$ & $\pm 0 \cdot 01$ & $\pm 0 \cdot 01$ & $\pm 0 \cdot 01$ & $\pm 0 \cdot 01$ & $\pm 0 \cdot 01$ \\
\hline $28 \cdot 77^{\mathrm{C}}$ & $29 \cdot 62^{c}$ & $31 \cdot 38^{b}$ & $35.62^{\mathrm{a}}$ & $36.75^{\mathrm{a}}$ & $36 \cdot 23^{a}$ \\
\hline \pm 0.61 & \pm 0.63 & \pm 0.64 & $\pm 0 \cdot 70$ & $\pm 0 \cdot 49$ & $\pm 0 \cdot 39$ \\
\hline $2 \cdot 31^{\mathrm{a}}$ & $2 \cdot 27^{\mathrm{a}}$ & $1.93^{b}$ & $1 \cdot 84^{b}$ & $1 \cdot 78^{\mathrm{b}}$ & $1 \cdot 82^{b}$ \\
\hline $\pm 0 \cdot 16$ & $\pm 0 \cdot 14$ & $\pm 0 \cdot 12$ & \pm 0.08 & \pm 0.06 & $\pm 0 \cdot 05$ \\
\hline $0 \cdot 46^{\mathrm{a}}$ & $0 \cdot 38^{b}$ & $0 \cdot 37^{b}$ & $0 \cdot 38^{b}$ & $0 \cdot 36^{b}$ & $0 \cdot 34^{\mathrm{b}}$ \\
\hline \pm 0.01 & \pm 0.02 & \pm 0.02 & \pm 0.02 & $\pm 0 \cdot 01$ & $\pm 0 \cdot 01$ \\
\hline $0 \cdot 37^{\mathrm{a}}$ & $0 \cdot 35^{\mathrm{a}}$ & $0 \cdot 26^{b}$ & $0 \cdot 22^{\mathrm{bc}}$ & $0 \cdot 19^{c}$ & $0 \cdot 19^{\mathrm{c}}$ \\
\hline $\pm 0 \cdot 02$ & \pm 0.02 & \pm 0.02 & $\pm 0 \cdot 02$ & $\pm 0 \cdot 01$ & $\pm 0 \cdot 01$ \\
\hline $12 \cdot 88^{\mathrm{a}}$ & $10 \cdot 87^{b}$ & $10 \cdot 17^{b}$ & $8.92^{\mathrm{C}}$ & $8 \cdot 56^{\mathrm{c}}$ & $8 \cdot 54^{\mathrm{c}}$ \\
\hline $\pm 0 \cdot 33$ & $\pm 0 \cdot 29$ & $\pm 0 \cdot 36$ & $\pm 0 \cdot 28$ & $\pm 0 \cdot 22$ & $\pm 0 \cdot 17$ \\
\hline $0 \cdot 40$ & $0 \cdot 39$ & $0 \cdot 42$ & $0 \cdot 42$ & $0 \cdot 40$ & $0 \cdot 42$ \\
\hline $\pm 0 \cdot 03$ & $\pm 0 \cdot 02$ & $\pm 0 \cdot 01$ & $\pm 0 \cdot 01$ & $\pm 0 \cdot 01$ & $\pm 0 \cdot 01$ \\
\hline $1 \cdot 01^{\mathrm{bc}}$ & $0.94^{c}$ & $1 \cdot 06^{\mathrm{bc}}$ & $1 \cdot 11^{\mathrm{ab}}$ & $1 \cdot 15^{\mathrm{ab}}$ & $1 \cdot 23^{\mathrm{a}}$ \\
\hline $\pm 0 \cdot 09$ & $\pm 0 \cdot 05$ & \pm 0.04 & $\pm 0 \cdot 05$ & $\pm 0 \cdot 04$ & $\pm 0 \cdot 04$ \\
\hline $25.75^{a}$ & $23.96^{\mathrm{a}}$ & $19 \cdot 89^{b}$ & $16 \cdot 16^{\mathrm{c}}$ & $15 \cdot 00^{C}$ & $15 \cdot 30^{C}$ \\
\hline $\pm 1 \cdot 22$ & $\pm 1 \cdot 05$ & \pm 0.89 & \pm 0.69 & \pm 0.46 & $\pm 0 \cdot 24$ \\
\hline $1 \cdot 06^{\mathrm{a}}$ & $1 \cdot 01^{\mathrm{ab}}$ & $0.92^{\mathrm{abc}}$ & $0 \cdot 76^{\mathrm{bcd}}$ & $0 \cdot 68^{\mathrm{cd}}$ & $0.63^{d}$ \\
\hline \pm 0.09 & \pm 0.09 & $\pm 0 \cdot 07$ & $\pm 0 \cdot 08$ & $\pm 0 \cdot 06$ & $\pm 0 \cdot 05$ \\
\hline $0 \cdot 24^{\mathrm{c}}$ & $0 \cdot 25^{\mathrm{c}}$ & $0 \cdot 26^{\mathrm{bc}}$ & $0 \cdot 26^{\mathrm{bc}}$ & $0 \cdot 29^{\mathrm{ab}}$ & $0 \cdot 29^{a}$ \\
\hline $\pm 0 \cdot 01$ & $\pm 0 \cdot 01$ & $\pm 0 \cdot 01$ & $\pm 0 \cdot 01$ & $\pm 0 \cdot 01$ & $\pm 0 \cdot 01$ \\
\hline 1.95 & $1 \cdot 89$ & 1.94 & $1 \cdot 84$ & $1 \cdot 79$ & $1 \cdot 77$ \\
\hline \pm 0.05 & \pm 0.06 & \pm 0.06 & \pm 0.05 & $\pm 0 \cdot 04$ & $\pm 0 \cdot 04$ \\
\hline $0 \cdot 38^{\mathrm{ab}}$ & $0 \cdot 34^{\mathrm{bc}}$ & $0 \cdot 35^{\mathrm{bc}}$ & $0.33^{c}$ & $0 \cdot 40^{\mathrm{a}}$ & $0 \cdot 39^{\mathrm{a}}$ \\
\hline $\pm 0 \cdot 01$ & \pm 0.01 & $\pm 0 \cdot 01$ & $\pm 0 \cdot 01$ & $\pm 0 \cdot 01$ & $\pm 0 \cdot 01$ \\
\hline $0 \cdot 35^{b}$ & $0 \cdot 34^{\mathrm{b}}$ & $0 \cdot 34^{b}$ & $0 \cdot 37^{b}$ & $0.43^{\mathrm{a}}$ & $0 \cdot 48^{\mathrm{a}}$ \\
\hline \pm 0.02 & $\pm 0 \cdot 02$ & $\pm 0 \cdot 01$ & $\pm 0 \cdot 01$ & $\pm 0 \cdot 01$ & $\pm 0 \cdot 02$ \\
\hline $0 \cdot 04$ & 0.03 & 0.03 & $0 \cdot 02$ & 0.03 & 0.03 \\
\hline $\pm 0 \cdot 01$ & $\pm 0 \cdot 01$ & $\pm 0 \cdot 01$ & $\pm 0 \cdot 01$ & $\pm 0 \cdot 01$ & $\pm 0 \cdot 01$ \\
\hline
\end{tabular}




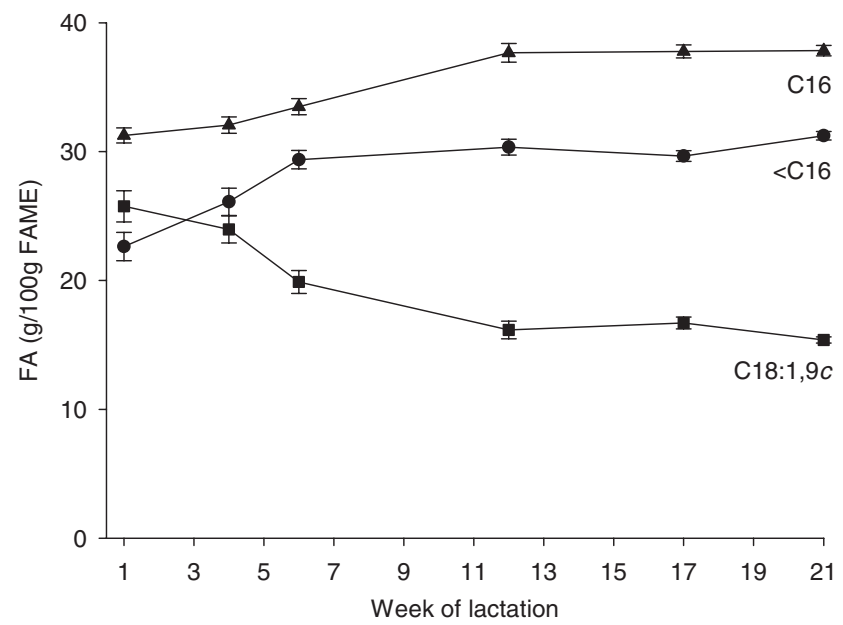

Fig. 2. Proportions (g/100 g of fatty acid methyl esters, FAME) of denovo synthesized FA (<C16; circles), C16 FA (triangles) and C18:1,9C (squares) in milk fat during the first 21 weeks of lactation in dairy cows.

of lactation (Tables 2 and 4). Besides energy supply the dietary composition also was changed in the group of RES cows during period 2 as the amount of the PMR and the concentrate was limited. Additionally, PMR 2 fed to RES cows included more hay than the PMR 1 fed to CON cows. Despite the higher induced NEB by feed restriction compared with the NEB in early lactation, plasma NEFA and BHBA concentrations were elevated only moderately in RES cows compared with CON cows during period 2 $(0.23 \pm 0.02$ v. $0.14 \pm 0.01 \mathrm{mmol} / \mathrm{l}$ and $0.62 \pm 0.03 \mathrm{v}$. $0 \cdot 52 \pm 0 \cdot 02 \mathrm{mmol} / \mathrm{l}$, respectively).

Milk fat content was elevated during feed restriction for RES cows (Table 4). Changes in milk yield and composition have been discussed in Gross et al. (2011). Data on the effect of energy balance on milk fat composition are scarce (Stoop et al. 2009). In the present study, milk FA profile of CON cows was stable during the whole time of periods 2 and 3. For RES cows, the proportion of most FA $\leqslant 16: 0$ (e.g. 6:0, $10: 0,10: 1,12: 0,14: 0,16: 0)$ was decreased during the NEB induced by feed restriction compared with the respective initial values, whereas preformed FA, especially $17: 1,9 c$, 18:0 and $18: 1,9 \mathrm{C}$ arising from body fat mobilization increased markedly during feed restriction (Table 5). These changes occurred rapidly within the first week of feed restriction (on average $3 \mathrm{~d}$ distance between the start of feed restriction and the next milking sample) and disappeared completely within one week of realimentation ( $4 \mathrm{~d}$ on average). The proportion of CLA in milk fat of RES cows was elevated at the start of feed restriction and adjusted immediately to initial values (Table 5). The rise of CLA in RES cows may be attributed to the changed diet towards less concentrate and more roughage. Despite the maintenance of the deliberately induced NEB by feed restriction at a relatively constant level, FA showed a tendency during the NEB to adjust towards the initial levels with progressing feed restriction. The pattern of decreasing short-chain FA and increase of long-chain FA during an induced NEB was reported in an earlier study of Luick \& Smith (1963). During feed restriction (period 2), SFA decreased, while MUFA (especially 18:1,9c) increased for RES cows compared with CON cows (Fig. 3). PUFA were stable during period 2 and the following realimentation period in RES cows (Table 5).

Luick \& Smith (1963) examined whether changes in milk FA composition during feed restriction are caused by a decreased synthesis of short-chain FA or by an increased incorporation of long-chain FA absorbed from plasma. According to Luick \& Smith (1963), the failure to utilize betahydroxybutyrate occurs when its concentration in plasma is elevated, i.e. during fasting and ketosis. This in turn, accounts for the relatively high levels of oleic acid found in milk fat of fasting and ketotic cows (Luick \& Smith, 1963) as observed in the present study. Although less in their extent, milk FA in the present study clearly showed a similar pattern during a deliberately induced NEB by feed restriction at around 100 DIM compared with the NEB in early lactation. Compared with milk of dairy cows in positive energy balance (week $14 \mathrm{pp}$ ), proportions for single FA (e.g. $17: 1,9 c ; 18: 1,9 c)$ were changed up to $80 \%$ during the NEB in early lactation and during the deliberately induced NEB by feed restriction.

Van Haelst et al. (2008) determined whether concentrations of specific FA in milk fat are suitable for the early detection of subclinical ketosis as mobilization of adipose tissue precedes development of ketosis (Reist et al. 2003). Van Haelst et al. (2008) suggested the elevated proportion of $18: 1,9 \mathrm{C}$ as an interesting trait for prediction of subclinical ketosis, particularly since this FA was elevated in milk fat before diagnosis of ketosis. As milk FA changed with altering energy balance, it is obvious to identify milk FA indicating a NEB in dairy cows independent of their lactational stage. Therefore, correlations between milk FA and the energy balance of all cows were calculated. Correlation over all cows between energy balance and the proportion of $18: 1,9 \mathrm{C}$ was $0 \cdot 77$. We wanted to investigate whether the correlation is higher in cows with a higher NEB. Thus the correlation between energy balance and the proportion of $18: 1,9 c$ in milk fat of 5 cows with the most negative EB in week 1 pp $(-80 \cdot 2 \mathrm{MJ} \mathrm{NEL} / \mathrm{d})$ was calculated, but did not show a closer relationship $(r=0 \cdot 62)$. The correlation between $E B$ and $18: 1,9 c$ for RES cows with the highest NEB in the first week of feed restriction $(-83 \cdot 2 \mathrm{MJ} \mathrm{NEL/d})$ was $0 \cdot 92$. From these results, an elevated proportion of $18: 1,9 \mathrm{c}$ in milk fat can be confirmed to be a suitable marker for a NEB. The correlation between energy balance and a single FA during the NEB in early lactation and during the deliberately induced NEB ranged from $0 \cdot 71$ to $0 \cdot 96$. However, the low proportion and relatively high variation in changed FA (e.g. $11: 0 ; 12: 1$; Tables 3 and 5) restrict the predictive value of these FA to indicate a NEB although changes were significant between RES and CON cows. On the contrary, the correlation between energy balance and groups of FA was higher in cows with a more intense NEB during feed 
Table 4. Milk yield and milk composition for feed-restricted (RES) and control cows (CON) during feed restriction and realimentation. For differences over time within group, values without a common superscript are significantly different $(P>0 \cdot 05)$, significant differences between RES- and CON-group within week are marked with * $(P<0 \cdot 05)$

Restricted Group $(n=20)$

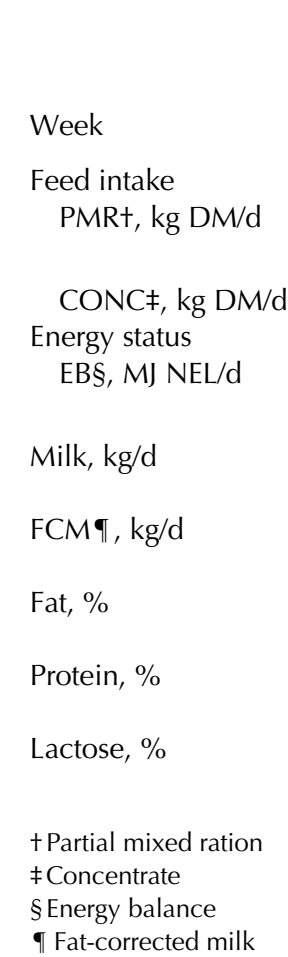

\begin{tabular}{ccccccc}
\hline & Period 2 & & & \multicolumn{2}{c}{ Period 3} \\
& 1 & 2 & 3 & & 1
\end{tabular}

$\begin{array}{cc}17 \cdot 0^{\mathrm{a}} & 9 \cdot 4^{* \mathrm{c}} \\ \pm 0 \cdot 7 & \pm 0 \cdot 3 \\ 5 \cdot 5^{\mathrm{a}} & 1 \cdot 2^{*^{\mathrm{d}}} \\ \pm 0 \cdot 5 & \pm 0 \cdot 1 \\ 9 \cdot 9^{\mathrm{a}} & -68 \cdot 0^{* \mathrm{c}} \\ \pm 2 \cdot 8 & \pm 2 \cdot 8\end{array}$

$33 \cdot 4^{\mathrm{a}} \quad 29 \cdot 3^{\mathrm{bc}}$

$\pm 1 \cdot 2 \quad \pm 1 \cdot 1$

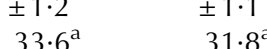

$\pm 1 \cdot 0$

$4 \cdot 11^{* b}$

$\pm 0 \cdot 13$

$3 \cdot 38^{\mathrm{ab}}$
$+0 \cdot 06$

$4 \cdot 80^{\mathrm{a}}$

$\pm 0.02$

$31 \cdot 8^{\mathrm{a}}$
$+1 \cdot 0$

$4.64^{\mathrm{a}}$

$\pm 0 \cdot 17$

$3 \cdot 21^{* b c}$

$\pm 0.06$

$4 \cdot 79$
\pm 0.02

$9 \cdot 6^{* \mathrm{c}}$
$\pm 0 \cdot 3$
$0 \cdot 4^{* \mathrm{e}}$
$\pm 0 \cdot 0$
$-64 \cdot 7^{* \mathrm{c}}$
$\pm 3 \cdot 9$

(2)

$9 \cdot 8^{* \mathrm{c}}$
$\pm 0 \cdot 3$
$0 \cdot 4^{* \mathrm{e}}$
$\pm 0 \cdot 0$
$-61 \cdot 8^{* \mathrm{c}}$
$\pm 4 \cdot 2$

$15 \cdot 6 *$

$\begin{array}{cc}15 \cdot 6^{* \mathrm{~b}} & 16 \cdot 9^{\mathrm{a}} \\ \pm 0 \cdot 4 & \pm 0 \cdot 5 \\ 2 \cdot 9^{* \mathrm{c}} & 4 \cdot 2^{\mathrm{b}} \\ \pm 0 \cdot 3 & \pm 0 \cdot 4 \\ -4 \cdot 6^{* \mathrm{~b}} & 6 \cdot 2^{\mathrm{a}} \\ \pm 2 \cdot 7 & \pm 3 \cdot 3\end{array}$

$27 \cdot 9^{\text {bc }}$

$\pm 1 \cdot 0$

$29 \cdot 0 *$ bc

$\pm 0.9$

$4 \cdot 31^{\mathrm{ab}}$

$\pm 0 \cdot 12$

$3 \cdot 18^{* \mathrm{C}}$

$\pm 0.06$

4.80
\pm 0.02

$\pm 4 \cdot 2$

$27 \cdot 2^{\mathrm{c}}$
+0.9

\pm 0.9
$28.6^{* \mathrm{c}}$

$\pm 0 \cdot 9$

$4.38^{\mathrm{ab}}$

$\pm 0 \cdot 14$

$3 \cdot 18^{* \mathrm{C}}$

$\pm 0.07$

$4 \cdot 75^{\mathrm{ab}}$

$\pm 0.02$

$\pm 2 \cdot 7$

$28 \cdot 3^{\text {bc }}$

$\pm 1 \cdot 1$

$28 \cdot 9^{\mathrm{bc}}$

$\pm \cdot 1$
$4 \cdot 19^{b}$

$+0 \cdot 13$

$3.33^{a b c}$

$\pm 0 \cdot 05$

$4 \cdot 71$
$\pm 0 \cdot 02$

$30 \cdot 4^{\mathrm{ab}}$

$\pm 1 \cdot 3$

$31 \cdot 3^{\mathrm{ab}}$

$\pm 1 \cdot 1$

$4 \cdot 28^{\mathrm{ab}}$

$\pm 0 \cdot 15$

\pm 0.15
$3.43^{\mathrm{a}}$

$\pm 0.05$

$4.73^{b}$

$\pm 0 \cdot 03$
Control Group $(n=20)$

\begin{tabular}{|c|c|c|c|}
\hline & Period 2 & & Period 3 \\
\hline 0 & 2 & 3 & 1 \\
\hline
\end{tabular}

$\begin{array}{llll}0 & 1 & 2 & 3\end{array}$

$\begin{array}{rr}16 \cdot 4^{\mathrm{ab}} & 15 \cdot 6^{\mathrm{b}} \\ \pm 0 \cdot 5 & \pm 0 \cdot 3 \\ 5 \cdot 4 & 5 \cdot 2 \\ \pm 0 \cdot 5 & \pm 0 \cdot 5 \\ 3 \cdot 7 & 0 \cdot 8 \\ \pm 2 \cdot 9 & \pm 3 \cdot 2\end{array}$

$\begin{array}{ll}17 \cdot 3^{\mathrm{a}} & 16 \cdot 9^{\mathrm{a}} \\ \pm 0 \cdot 5 & \pm 0 \cdot 4\end{array}$

$\pm 0 \cdot 5 \quad \pm 0 \cdot 4$

$\begin{array}{rr}4.8 & 4.7 \\ \pm 0.5 & \pm 0.5\end{array}$

$8 \cdot 1$

$\pm 3 \cdot 8$

$\pm 0 \cdot 5$
$8 \cdot 9$

$\pm 4 \cdot 7$

$32 \cdot 3$

$\pm 1 \cdot 5$

$34 \cdot 2^{\mathrm{a}}$

$\pm 1 \cdot 2$

$31 \cdot 1 \quad 31 \cdot 1 \quad 29 \cdot 7$

$\pm 1 \cdot 4 \quad \pm 1 \cdot 3 \quad \pm 1 \cdot 3$

$32 \cdot 8^{\mathrm{ab}}$

$33 \cdot 0^{\mathrm{ab}}$

$\pm 1 \cdot 2$

$31 \cdot 9^{\mathrm{ab}}$

$4 \cdot 41$

$4 \cdot 45$

$\pm 1 \cdot 4$
$4 \cdot 48$

$\pm 0 \cdot 19$

$3 \cdot 41$
$+0 \cdot 06$

$4 \cdot 74$

$\pm 0 \cdot 11$

$\pm 0 \cdot 11$

$\pm 0 \cdot 05$

$\pm 0 \cdot 05$

$\pm 0.08$

$3 \cdot 43$
$\pm 0 \cdot 06$
$4 \cdot 75$

$16 \cdot 3^{\mathrm{ab}} \quad 17 \cdot 0^{\mathrm{a}}$

$\pm 0 \cdot 4 \quad \pm 0 \cdot 5$

$4.4 \quad 4.3$

$\pm 0 \cdot 4 \quad \pm 0 \cdot 5$

$\begin{array}{rr}5 \cdot 8 & 9 \cdot 9\end{array}$

$\pm 3 \cdot 5 \quad \pm 3 \cdot 6$

$28 \cdot 8 \quad 28 \cdot 8$

$\pm 1 \cdot 1 \quad \pm 1 \cdot 3$

$30 \cdot 8^{\mathrm{ab}} \quad 30 \cdot 6^{\mathrm{b}}$

$\pm 1 \cdot 1 \quad \pm 1 \cdot 2$

$4.49 \quad 4.48$

$\pm 0 \cdot 13 \quad \pm 0 \cdot 13$

$3.43 \quad 3.48$

$\pm 0.06 \quad \pm 0.06$

$\begin{array}{lll}4.75 & 4.74 & 4.73\end{array}$

$\pm 0.03 \quad \pm 0.02 \quad \pm 0.03 \quad \pm 0.03$ 
Table 5. Milk fatty acid (FA) composition (g/100 g fatty acid methyl esters, FAME) for feed-restricted (RES) and control cows (CON) during feed restriction and realimentation. For differences over time within group, values without a common superscript are significantly different $(P>0 \cdot 05)$, significant differences between RES- and CON-group within week are marked with * $(P<0 \cdot 05)$

Restricted Group $(n=20)$

\begin{tabular}{|c|c|c|c|c|c|c|c|c|c|c|c|c|}
\hline \multirow[b]{2}{*}{ Week } & \multicolumn{4}{|c|}{ Period 2} & \multicolumn{2}{|c|}{ Period 3} & \multicolumn{4}{|c|}{ Period 2} & \multicolumn{2}{|c|}{ Period 3} \\
\hline & 0 & 1 & 2 & 3 & 1 & 2 & 0 & 1 & 2 & 3 & 1 & 2 \\
\hline \multicolumn{13}{|c|}{ FA (g/100g FAME) } \\
\hline \multirow[t]{2}{*}{$4: 0$} & $2 \cdot 97$ & $3 \cdot 03$ & $3 \cdot 15$ & $3 \cdot 17$ & $3 \cdot 21$ & $3 \cdot 13$ & $3 \cdot 08$ & $3 \cdot 10$ & $3 \cdot 17$ & $3 \cdot 10$ & $3 \cdot 10$ & $3 \cdot 03$ \\
\hline & $\pm 0 \cdot 07$ & $\pm 0 \cdot 10$ & $\pm 0 \cdot 11$ & $\pm 0 \cdot 12$ & $\pm 0 \cdot 13$ & $\pm 0 \cdot 11$ & $\pm 0 \cdot 08$ & $\pm 0 \cdot 05$ & $\pm 0 \cdot 12$ & $\pm 0 \cdot 07$ & $\pm 0 \cdot 07$ & \pm 0.05 \\
\hline \multirow[t]{2}{*}{$6: 0$} & $2 \cdot 35^{\mathrm{a}}$ & $2 \cdot 15^{* b}$ & $2 \cdot 30^{\mathrm{ab}}$ & $2 \cdot 32^{\mathrm{ab}}$ & $2 \cdot 45^{\mathrm{a}}$ & $2 \cdot 42^{\mathrm{a}}$ & $2 \cdot 41$ & $2 \cdot 38$ & $2 \cdot 46$ & $2 \cdot 40$ & $2 \cdot 41$ & $2 \cdot 34$ \\
\hline & $\pm 0 \cdot 06$ & $\pm 0 \cdot 04$ & \pm 0.06 & \pm 0.07 & $\pm 0 \cdot 08$ & \pm 0.03 & $\pm 0 \cdot 04$ & $\pm 0 \cdot 04$ & $\pm 0 \cdot 06$ & $\pm 0 \cdot 05$ & $\pm 0 \cdot 05$ & \pm 0.03 \\
\hline \multirow[t]{2}{*}{$8: 0$} & $1 \cdot 51^{\mathrm{a}}$ & $1 \cdot 29 * b$ & $1 \cdot 36^{* b}$ & $1 \cdot 38^{* b}$ & $1 \cdot 53^{\mathrm{a}}$ & $1 \cdot 54^{\mathrm{a}}$ & $1 \cdot 53$ & $1 \cdot 49$ & $1 \cdot 55$ & $1 \cdot 51$ & $1 \cdot 52$ & $1 \cdot 47$ \\
\hline & $\pm 0 \cdot 04$ & $\pm 0 \cdot 03$ & $\pm 0 \cdot 03$ & $\pm 0 \cdot 04$ & $\pm 0 \cdot 04$ & $\pm 0 \cdot 04$ & $\pm 0 \cdot 03$ & $\pm 0 \cdot 04$ & $\pm 0 \cdot 03$ & $\pm 0 \cdot 04$ & $\pm 0 \cdot 03$ & \pm 0.03 \\
\hline \multirow[t]{2}{*}{ 10:0 } & $3 \cdot 60^{\mathrm{a}}$ & $2 \cdot 79 * b$ & $2 \cdot 96^{* b}$ & $3 \cdot 05^{* b}$ & $3 \cdot 59^{a}$ & $3.64^{\mathrm{a}}$ & $3 \cdot 73$ & $3 \cdot 54$ & $3 \cdot 70$ & $3 \cdot 61$ & $3 \cdot 62$ & $3 \cdot 48$ \\
\hline & \pm 0.08 & $\pm 0 \cdot 10$ & $\pm 0 \cdot 09$ & $\pm 0 \cdot 10$ & $\pm 0 \cdot 10$ & $\pm 0 \cdot 10$ & \pm 0.09 & $\pm 0 \cdot 11$ & \pm 0.09 & $\pm 0 \cdot 11$ & $\pm 0 \cdot 10$ & \pm 0.08 \\
\hline \multirow[t]{2}{*}{$10: 1$} & $0 \cdot 36^{\mathrm{a}}$ & $0 \cdot 27^{* \mathrm{C}}$ & $0 \cdot 29 * \mathrm{bc}$ & $0 \cdot 32^{\mathrm{b}}$ & $0 \cdot 39^{*^{\mathrm{a}}}$ & $0 \cdot 38^{*^{\mathrm{a}}}$ & $0 \cdot 34$ & $0 \cdot 32$ & $0 \cdot 33$ & $0 \cdot 32$ & $0 \cdot 33$ & $0 \cdot 32$ \\
\hline & $\pm 0 \cdot 01$ & $\pm 0 \cdot 01$ & $\pm 0 \cdot 01$ & $\pm 0 \cdot 01$ & $\pm 0 \cdot 01$ & $\pm 0 \cdot 01$ & $\pm 0 \cdot 01$ & $\pm 0 \cdot 01$ & $\pm 0 \cdot 01$ & $\pm 0 \cdot 01$ & $\pm 0 \cdot 02$ & \pm 0.01 \\
\hline \multirow[t]{2}{*}{$12: 0$} & $4 \cdot 27^{\mathrm{a}}$ & $3 \cdot 18^{* b}$ & $3 \cdot 32^{* b}$ & $3 \cdot 49 * b$ & $4 \cdot 34^{\mathrm{a}}$ & $4 \cdot 37^{\mathrm{a}}$ & $4 \cdot 47$ & $4 \cdot 16$ & $4 \cdot 35$ & $4 \cdot 27$ & $4 \cdot 28$ & $4 \cdot 10$ \\
\hline & $\pm 0 \cdot 08$ & $\pm 0 \cdot 13$ & $\pm 0 \cdot 13$ & $\pm 0 \cdot 13$ & $\pm 0 \cdot 13$ & $\pm 0 \cdot 13$ & $\pm 0 \cdot 13$ & $\pm 0 \cdot 15$ & $\pm 0 \cdot 12$ & $\pm 0 \cdot 14$ & $\pm 0 \cdot 13$ & $\pm 0 \cdot 10$ \\
\hline \multirow[t]{2}{*}{$12: 1$} & $0 \cdot 11^{\mathrm{b}}$ & $0 \cdot 07^{* \mathrm{~d}}$ & $0.08^{* \mathrm{~cd}}$ & $0.09^{c}$ & $0 \cdot 13^{* a}$ & $0 \cdot 12^{* a}$ & $0 \cdot 10$ & 0.09 & $0 \cdot 10$ & $0 \cdot 10$ & $0 \cdot 10$ & $0 \cdot 10$ \\
\hline & $\pm 0 \cdot 00$ & $\pm 0 \cdot 00$ & $\pm 0 \cdot 00$ & $\pm 0 \cdot 01$ & $\pm 0 \cdot 01$ & $\pm 0 \cdot 00$ & $\pm 0 \cdot 00$ & $\pm 0 \cdot 01$ & $\pm 0 \cdot 00$ & $\pm 0 \cdot 00$ & $\pm 0 \cdot 01$ & \pm 0.00 \\
\hline \multirow[t]{2}{*}{ 14:0iso } & $0 \cdot 08^{b}$ & $0.09^{\mathrm{ab}}$ & $0 \cdot 10^{\mathrm{a}}$ & $0 \cdot 10^{\mathrm{ab}}$ & $0 \cdot 08^{* b}$ & $0.09^{b}$ & $0 \cdot 09$ & 0.09 & 0.09 & $0 \cdot 10$ & $0 \cdot 11$ & $0 \cdot 10$ \\
\hline & $\pm 0 \cdot 01$ & $\pm 0 \cdot 01$ & $\pm 0 \cdot 01$ & \pm 0.00 & $\pm 0 \cdot 01$ & $\pm 0 \cdot 01$ & $\pm 0 \cdot 01$ & $\pm 0 \cdot 01$ & $\pm 0 \cdot 01$ & $\pm 0 \cdot 01$ & $\pm 0 \cdot 01$ & $\pm 0 \cdot 01$ \\
\hline \multirow[t]{2}{*}{$14: 0$} & $12 \cdot 38^{\mathrm{a}}$ & $10 \cdot 95^{* b}$ & $11 \cdot 38^{* b}$ & $11 \cdot 46^{b}$ & $12 \cdot 26^{\mathrm{a}}$ & $12 \cdot 29^{a}$ & $12 \cdot 36$ & $12 \cdot 00$ & $12 \cdot 20$ & $12 \cdot 18$ & $12 \cdot 29$ & $12 \cdot 03$ \\
\hline & $\pm 0 \cdot 16$ & $\pm 0 \cdot 29$ & $\pm 0 \cdot 22$ & $\pm 0 \cdot 22$ & $\pm 0 \cdot 21$ & $\pm 0 \cdot 18$ & $\pm 0 \cdot 19$ & $\pm 0 \cdot 28$ & $\pm 0 \cdot 22$ & $\pm 0 \cdot 24$ & $\pm 0 \cdot 22$ & $\pm 0 \cdot 25$ \\
\hline \multirow[t]{2}{*}{$14: 1,9 \mathrm{C}$} & $1 \cdot 40^{\mathrm{ab}}$ & $1 \cdot 14^{\mathrm{b}}$ & $1 \cdot 21^{\mathrm{ab}}$ & $1 \cdot 27^{\mathrm{ab}}$ & $1 \cdot 50^{\mathrm{a}}$ & $1 \cdot 50^{a}$ & $1 \cdot 13$ & 1.07 & 1.08 & 1.07 & $1 \cdot 14$ & 1.51 \\
\hline & $\pm 0 \cdot 13$ & $\pm 0 \cdot 10$ & $\pm 0 \cdot 10$ & $\pm 0 \cdot 08$ & $\pm 0 \cdot 12$ & $\pm 0 \cdot 14$ & \pm 0.05 & \pm 0.06 & \pm 0.05 & \pm 0.05 & \pm 0.06 & $\pm 0 \cdot 12$ \\
\hline \multirow[t]{2}{*}{$15: 0$} & $1 \cdot 44^{\mathrm{a}}$ & $1 \cdot 00^{* b}$ & $1 \cdot 01^{* b}$ & $1 \cdot 04^{\mathrm{b}}$ & $1 \cdot 26^{a}$ & $1 \cdot 37^{\mathrm{a}}$ & $1 \cdot 29$ & $1 \cdot 21$ & $1 \cdot 26$ & $1 \cdot 22$ & $1 \cdot 24$ & $1 \cdot 22$ \\
\hline & \pm 0.09 & $\pm 0 \cdot 05$ & \pm 0.05 & $\pm 0 \cdot 04$ & \pm 0.06 & \pm 0.09 & \pm 0.07 & \pm 0.07 & \pm 0.09 & \pm 0.07 & \pm 0.07 & \pm 0.07 \\
\hline \multirow[t]{2}{*}{ 16:0iso } & $0 \cdot 18^{\mathrm{b}}$ & $0 \cdot 24^{\mathrm{a}}$ & $0 \cdot 24^{\mathrm{a}}$ & $0 \cdot 22^{\mathrm{ab}}$ & $0 \cdot 20^{b}$ & $0 \cdot 19^{* b}$ & $0 \cdot 21$ & $0 \cdot 21$ & $0 \cdot 22$ & $0 \cdot 22$ & $0 \cdot 22$ & $0 \cdot 23$ \\
\hline & $\pm 0 \cdot 01$ & $\pm 0 \cdot 01$ & $\pm 0 \cdot 01$ & $\pm 0 \cdot 01$ & $\pm 0 \cdot 01$ & $\pm 0 \cdot 01$ & $\pm 0 \cdot 01$ & $\pm 0 \cdot 01$ & $\pm 0 \cdot 01$ & $\pm 0 \cdot 02$ & $\pm 0 \cdot 01$ & \pm 0.02 \\
\hline \multirow[t]{2}{*}{$16: 0$} & $36 \cdot 14^{\mathrm{ab}}$ & $32 \cdot 63 * \mathrm{~d}$ & $33 \cdot 51 * \mathrm{~cd}$ & $34 \cdot 58^{* b c}$ & $37 \cdot 84^{a}$ & $36 \cdot 03^{\mathrm{ab}}$ & $37 \cdot 35$ & $36 \cdot 52$ & $36 \cdot 38$ & $36 \cdot 75$ & $36 \cdot 43$ & $36 \cdot 52$ \\
\hline & $\pm 0 \cdot 61$ & $\pm 0 \cdot 67$ & $\pm 0 \cdot 69$ & $\pm 0 \cdot 74$ & $\pm 0 \cdot 62$ & $\pm 0 \cdot 51$ & $\pm 0 \cdot 64$ & \pm 0.75 & $\pm 0 \cdot 73$ & $\pm 0 \cdot 55$ & \pm 0.69 & \pm 0.78 \\
\hline \multirow[t]{2}{*}{$16: 1,9 \mathrm{C}$} & $1 \cdot 86$ & 1.94 & 1.91 & 1.93 & 2.06 & 1.95 & $1 \cdot 85$ & $1 \cdot 86$ & $1 \cdot 80$ & $1 \cdot 78$ & $1 \cdot 84$ & $1 \cdot 83$ \\
\hline & $\pm 0 \cdot 08$ & $\pm 0 \cdot 09$ & $\pm 0 \cdot 08$ & $\pm 0 \cdot 08$ & $\pm 0 \cdot 09$ & $\pm 0 \cdot 08$ & \pm 0.08 & $\pm 0 \cdot 11$ & $\pm 0 \cdot 08$ & $\pm 0 \cdot 08$ & $\pm 0 \cdot 08$ & $\pm 0 \cdot 10$ \\
\hline \multirow[t]{2}{*}{$17: 0$} & $0 \cdot 39$ & $0 \cdot 39$ & $0 \cdot 37$ & $0 \cdot 36$ & $0 \cdot 34$ & $0 \cdot 36$ & $0 \cdot 37$ & $0 \cdot 37$ & $0 \cdot 36$ & $0 \cdot 36$ & $0 \cdot 36$ & $0 \cdot 36$ \\
\hline & \pm 0.02 & $\pm 0 \cdot 01$ & \pm 0.02 & \pm 0.02 & \pm 0.02 & \pm 0.02 & $\pm 0 \cdot 01$ & $\pm 0 \cdot 01$ & $\pm 0 \cdot 01$ & $\pm 0 \cdot 01$ & $\pm 0 \cdot 01$ & \pm 0.01 \\
\hline \multirow[t]{2}{*}{$17: 1,9 \mathrm{C}$} & $0 \cdot 21^{\mathrm{b}}$ & $0 \cdot 28^{* a}$ & $0 \cdot 26^{* a}$ & $0 \cdot 25^{* \mathrm{a}}$ & $0 \cdot 21^{b}$ & $0 \cdot 21^{\mathrm{b}}$ & $0 \cdot 20$ & $0 \cdot 21$ & $0 \cdot 19$ & $0 \cdot 19$ & $0 \cdot 20$ & $0 \cdot 19$ \\
\hline & $\pm 0 \cdot 01$ & $\pm 0 \cdot 02$ & $\pm 0 \cdot 01$ & \pm 0.02 & $\pm 0 \cdot 01$ & $\pm 0 \cdot 01$ & $\pm 0 \cdot 01$ & \pm 0.01 & $\pm 0 \cdot 01$ & $\pm 0 \cdot 01$ & $\pm 0 \cdot 01$ & \pm 0.01 \\
\hline \multirow[t]{2}{*}{ 18:0 } & $8 \cdot 22^{\mathrm{b}}$ & $10 \cdot 09^{* a}$ & $9 \cdot 86^{* \mathrm{a}}$ & $9 \cdot 46^{* a}$ & $7 \cdot 44^{* b}$ & $8 \cdot 19^{b}$ & 8.02 & $8 \cdot 56$ & 8.51 & $8 \cdot 56$ & 8.53 & 8.49 \\
\hline & $\pm 0 \cdot 19$ & $\pm 0 \cdot 22$ & $\pm 0 \cdot 29$ & $\pm 0 \cdot 35$ & $\pm 0 \cdot 32$ & $\pm 0 \cdot 25$ & $\pm 0 \cdot 25$ & $\pm 0 \cdot 41$ & $\pm 0 \cdot 33$ & $\pm 0 \cdot 24$ & $\pm 0 \cdot 36$ & \pm 0.39 \\
\hline
\end{tabular}




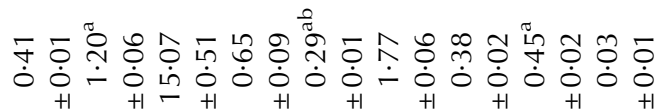

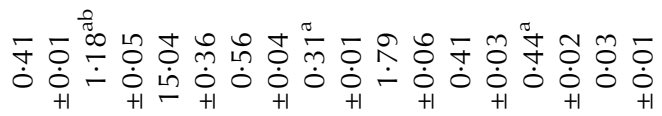

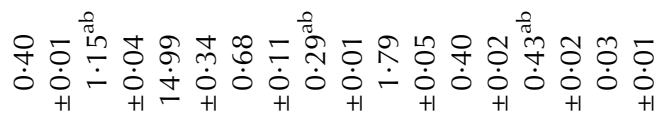

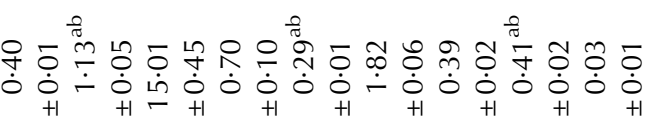

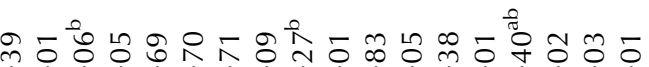

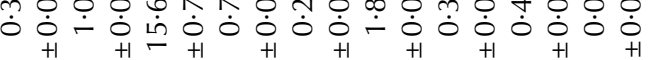

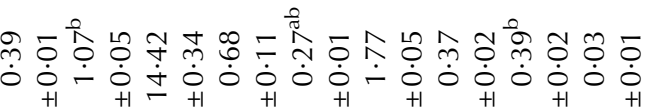

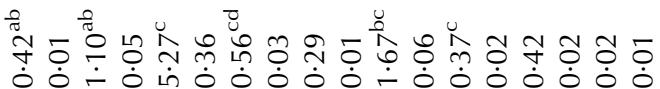

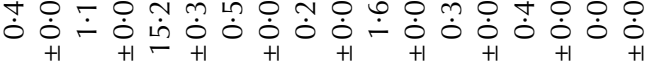

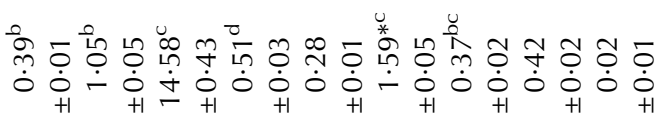

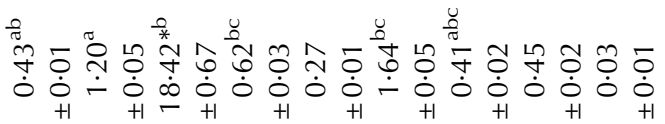

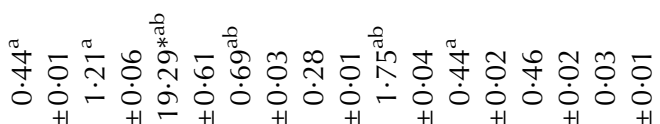

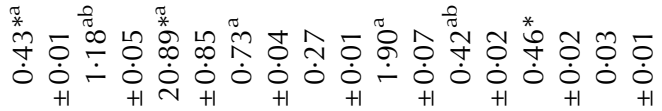

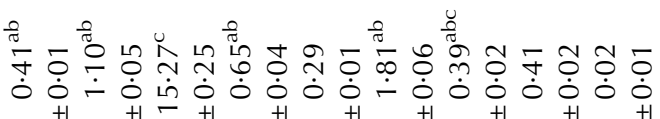

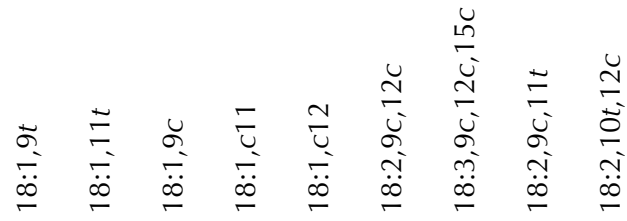

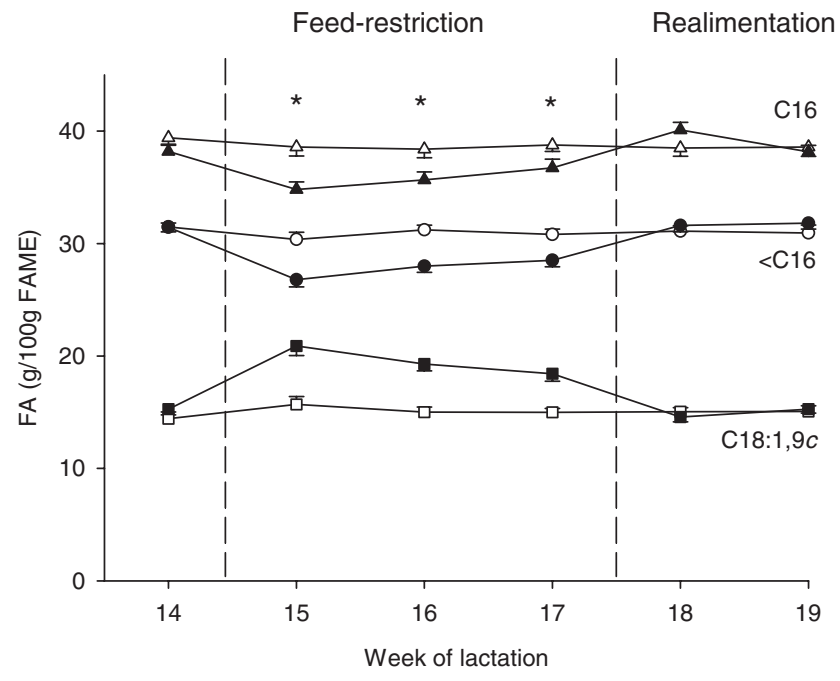

Fig. 3. Proportions (g/100 g of fatty acid methyl esters, FAME) of de-novo synthesized FA (<C16; circles), C16 FA (triangles) and C18:1,9c (squares) in milk fat of feed-restricted cows (filled symbols) and control cows (empty symbols) during feed restriction (weeks 15-17 post partum) and subsequent realimentation (weeks 18-19 post partum). Stars indicate a significant difference between the groups $(P<0 \cdot 05)$.

restriction that ranged from 0.92 up to 0.98 for SFA, MUFA (predominantly 18:1,9c), de-novo synthesized (sum of $\mathrm{FA}<\mathrm{C} 16, r=0.94$ ) and preformed FA (sum of FA $>$ C16, $r=0.92$ ). The higher proportion of these summarized FA in milk fat makes their changes a more appropriate tool reflecting energy balance in dairy cows compared with a single FA represented at a low concentration.

\section{Conclusions}

Post-partum changes in milk FA profile in the present study followed previous findings. Short- and medium-chain FA up to C16 increased with the decreasing NEB pp, while longchain FA, especially $18: 1,9 c$ decreased as mobilization of body fat reserves declined. The responses of FA profiles of cows' milk due to a NEB at two lactational stages in the present study - the NEB in early lactation and the deliberately induced NEB by feed restriction - was similarly directed. Despite the maintenance of a high NEB during the feed restriction period, changes in milk FA profile were less pronounced compared with changes during the NEB in early lactation and tended to adjust to the initial composition. However, milk FA profile changed within a few days after initiation of the deliberately induced NEB and showed no more differences within the first week of realimentation compared with control cows. For the dietary composition and feeding regimen in the present study, the close relationship with energy balance makes changes in $18: 1,9 \mathrm{C}$ as well as in groups of FA (SFA, MUFA, de-novo synthesized and preformed FA) suitable indicators of the energy balance in dairy cows. 


\section{References}

Bauman DE \& Davis CL 1974 Biosynthesis of milk fat. In: Lactation-A comprehensive treatise Vol. 2 (Eds BL Larson \& VR Smith) p. 31. New York, USA: Academic Press

Bligh EG \& Dyer WJ 1959 A rapid method of total lipid extraction and purification. Canadian Journal of Biochemistry and Physiology $\mathbf{3 7}$ 911-917

Bobe G, Lindberg GL, Freeman AE \& Beitz DC 2007 Short communication: Composition of milk protein and milk fatty acids is stable for cows differing in genetic merit for milk production. Journal of Dairy Science $\mathbf{9 0}$ 3955-3960

Dann HM, Morin DE, Bollero GA, Murphy MR \& Drackley JK 2005 Prepartum intake, postpartum induction of ketosis, and periparturient disorders affect the metabolic status of dairy cows. Journal of Dairy Science 88 3249-3264

Garnsworthy PC \& Huggett CD 1992 The influence of the fat concentration of the diet on the response by dairy cows to body condition at calving. Animal Production 54 7-13

Garnsworthy PC, Masson LL, Lock AL \& Mottram TT 2006 Variation of milk citrate with stage of lactation and de novo fatty acid synthesis in dairy cows. Journal of Dairy Science 89 1604-1612

GfE (German Society of Nutrition Physiology) 2001 [Recommendations on energy and nutrient requirements of dairy cows and rearing cattle], ed. Ausschuss für Bedarfsnormen der Gesellschaft für Ernährungsphysiologie. DLG-Verlag, Frankfurt am Main, Germany

Glantz M, Lindmark Mansson H, Stalhammar H, Barström L-O, Fröjelin M, Knutsson A, Teluk C \& Paulsson M 2009 Effects of animal selection on milk composition and processability. Journal of Dairy Science $\mathbf{9 2}$ 4589-4603

Gross J, van Dorland HA, Bruckmaier RM \& Schwarz FJ 2011 Performance and metabolic profile of dairy cows during a lactational and deliberately induced negative energy balance with subsequent realimentation. Journal of Dairy Science 94 1820-1830

Hallermayer R 1976 [A rapid method to determine fat content in food]. Deutsche Lebensmittelrundschau 10 356-359

Jensen RG, Ferris AM \& Lammi-Keefe CJ 1991 The composition of milk fat. Journal of Dairy Science 74 3228-3243

Kay JK, Weber WJ, Moore CE, Bauman DE, Hansen LB, Chester-Jones H, Crooker BA \& Baumgard LH 2005 Effects of week of lactation and genetic selection for milk yield on milk fatty acid composition in Holstein cows. Journal of Dairy Science 88 3886-3893

Kelsey JA, Corl BA, Collier RJ \& Bauman DE 2003 The effect of breed, parity, and stage of lactation on conjugated linoleic acid (CLA) in milk fat from dairy cows. Journal of Dairy Science $\mathbf{8 6} 2588$ 2597
Leiber F, Kreuzer M, Nigg D, Wettstein H-R \& Scheeder MRL 2005 A study on the causes for the elevated n-3 fatty acids in cows' milk of alpine origin. Lipids 40 191-202

Luick JR \& Smith LM 1963 Fatty acid synthesis during fasting and bovine ketosis. Journal of Dairy Science $\mathbf{4 6}$ 1251-1255

Moate PJ, Chalupa W, Boston RC \& Lean IJ 2007 Milk fatty acids. I. Variation in the concentration of individual fatty acids in bovine milk. Journal of Dairy Science 90 4730-4739

Moore JH \& Christie WW 1979 Lipid metabolism in the mammary gland of ruminant animals. Progress in Lipid Research 17 347-395

Naumann K, Bassler R, Seibold R \& Barth C 2000 [The chemical analysis of feedstuffs. Book of methods no. III], ed. Verband Deutscher Landwirtschaftlicher Untersuchungs- und Forschungsanstalten. Darmstadt, Germany: VDLUFA-Press

Palladino RA, O'Donovan M, Murphy JJ, McEvoy M, Callan J, Boland TM \& Kenny DA 2009 Fatty acid intake and milk fatty acid composition of Holstein dairy cows under different grazing strategies: Herbage mass and daily herbage allowance. Journal of Dairy Science 92 5212-5223

Palmquist DL, Beaulieu AD \& Barbano DM 1993 ADSA foundation symposium: Milk fat synthesis and modification. Feed and animal factors influencing milk fat composition. Journal of Dairy Science 76 1753-1771

Reist M, Erdin D, von Euw D, Tschuemperlin K, Leuenberger H, Delavaud C, Chilliard Y, Hammon HM, Kuenzi N \& Blum JW 2003 Concentrate feeding strategy in lactating dairy cow: Metabolic and endocrine changes with emphasis on leptin. Journal of Dairy Science 86 1690-1706

Rukkwamsuk T, Geelen MJH, Kruip TAM \& Wensing T 2000 Interrelation of fatty acid composition in adipose tissue, serum, and liver of dairy cows during the development of fatty liver postpartum. Journal of Dairy Science $8352-59$

Stoop WM, Bovenhuis H, Heck JML \& van Arendonk JAM 2009 Effect of lactation stage and energy status on milk fat composition of HolsteinFriesian cows. Journal of Dairy Science 92 1469-1478

Stull JW, Brown WH, Valdez C \& Tucker H 1966 Fatty acid composition of milk. III. Variation with stage of lactation. Journal of Dairy Science $\mathbf{4 9}$ 1401-1405

Tyburczy C, Lock AL, Dwyer DA, Destaillats F, Mouloungui Z, Candy L \& Bauman DE 2008 Uptake and utilization of trans octadecenoic acids in lactating cows. Journal of Dairy Science 91 3850-3861

Van Haelst YNT, Beeckman A, van Knegsel ATM \& Fievez V 2008 Short communication: Elevated concentrations of oleic acid and long-chain fatty acids in milk fat of multiparous subclinical ketotic cows. Journal of Dairy Science 91 4683-4686

Van Knegsel ATM, van den Brand H, Dijkstra J, Tamminga S \& Kemp B 2005 Effect of dietary energy source on energy balance, production metabolic disorders and reproduction in lactating dairy cattle. Review. Reproduction Nutrition Development 45 665-688 